\title{
The Orientation and Standards of Technology-applied Universities
}

\author{
Xiaoming $\mathrm{Li}^{1}$, Xiaoping Wang ${ }^{1}$, Xiling Wang ${ }^{1}$ \\ ${ }^{1}$ Xiangnan University, Chenzhou, Hunan Province, China
}

Keywords: Technology-Applied Universities, Orientation, Function, Setting Standard.

\begin{abstract}
Through the analyses and comparison of development statuses of higher occupation education in China and Europe, this paper identifies the gap between western and eastern higher occupation education, analyzes the orientation and functions of technology-applied universities in China, and discusses the setting standards of Chinese technology-applied universities mainly from the perspectives of personnel training, specialty setup, school-enterprise cooperation, faculty and the internationalization of schools.
\end{abstract}

\section{Problems and Gaps}

The higher occupation education system in China is different from occupation education in Europe. In China, there is no technology-applied university in real sense; the biggest problem in occupation education is the incomplete occupation education system. After finishing nine-year compulsory education, if a student want to receive occupation education, he or she can choose secondary vocational school or higher vocational school. The highest academic qualification which can be provided by vocational school is a three year specialist diploma. Meanwhile, post service education is now included in training system, rather than education system. In recent years, some colleges and universities adapt to the needs of society, and put forward to the orientation of "application-oriented" talent training method. But there is still a long way to go to realize the true higher vocational education.

Inspiration from applied science universities in Europe. Level of running schools. In Europe, technology-applied colleges and universities make up an important component of education system. They belong to higher education system, and have equal values with academic universities.

Training objectives. Through basic theoretical education and comprehensive vocational training, students are able to become high-level technical personnel who have professional skills in particular fields.

System environment. Government at all levels, enterprises, schools and other social groups should put enthusiasm in education, and provide positive guidance from policy guidance to financial support, teachers' recruiting, organization management and major setup.

System of running school. Major setup in schools should accords with social and industrial development; open and flexible modular curriculum system should also be introduced. More innovations should be made in teaching modes and teaching methods.

Teaching staff. "Dual system" should be used. Part-time teachers come from enterprises should become an important part of school education; the number of part-time teachers may even excess full-time university teachers.

Practical teaching: pay great attention to practice session. High-quality practice session almost occupies $1 / 2$ of the entire teaching link. It can reflect the vitality of higher education system.

Technology-applied universities bridge the gap from vocational schools to professional masters, and improve the higher occupation education system. The mutual conversion between technology-applied universities and common academic universities forms a "ladder", and constitutes the entire education system. 
Analysis of existing problems. Training mode. The training of applied talents remains at the level of specialist. Technology-applied undergraduate education has just started, and it will take a long time to cover postgraduate education.

The professional setting in vocational schools cannot meet the needs of all industries, and it is necessary to train all kinds of high-level applied talents for all trades and professions. Now the talents are specialty in single fields, and cannot be widely applied.

Schools need to speed up personnel training, and accelerate the transformation and restructuring of industries through high-tech and advanced technologies.

School enterprise cooperation. Enterprises in developed countries attach great importance to the cooperation with schools, and establish a complete set of personnel protection mechanism for the development of vocational education. This mechanism binds both schools and enterprises. The cooperation between higher occupation schools and enterprises in our country is still at low level, and does realize the win-win result. Enterprises cannot get benefits from cooperation, and are lack of enthusiasm. This is far from the stage of deep cooperation.

Faculty structure. In China, the building of "double-certificated" teacher's team in vocational schools is much slower than European technology universities. First, there is no clear access mechanism, and teachers are not required to have double qualifications or double abilities. Second, the number of senior teachers is not enough; the breadth and depth of cooperation with enterprises are not enough. Senior engineers are difficult to be introduced. Third, part-time teachers come from enterprises are inadequate. Fourth, full-time teachers who can take the responsibility of practical links are not enough.

\section{Orientation and Functions}

According to the International Standard Classification of Education, universities and colleges can be divided into three groups: theoretical schools, vocational schools and technical schools. On the basis analyzing the applied undergraduate education of Europe, especially Germany, it is found that technology-applied universities have following characteristics: (1) closely relate to economic development; (2) setup majors according to industry needs; (3) the focus of cultivation is undergraduate students; a certain degree of professional postgraduate education is also included; (4) teaching is the main task, applied researches are carried out at the same time. The main task is to cultivate applied talents who can adapt to needs of various industries. These talents, on the basis of mastering professional knowledge and technical skills, are able to satisfy higher technical requirements.

According to above characteristics, the training target of technology-applied universities is to train advanced applied talents for all walks of life. From the perspective of training level, the focus of cultivation is undergraduate students; a certain degree of professional postgraduate education is also included. From the perspective of specialty, majors are set up according to the development of local high-tech industry and industry needs. From the perspective of service oriented, technology-applied universities should serve local economic construction and social development.

The orientation of technology-applied universities determines its training goal, which is different both from academic or research undergraduate talents, and from practical or highly skilled personnel. Technology-applied universities set up majors according to industries and enterprises, and organize teaching activities in order to adapt to industry development and enterprises' needs. The theme of technology-applied universities is "application", and they need to construct curriculum system and teaching content on that basis, cultivate students' practice ability and the ability of solving actual problems according to scientific theory. Compared with academic undergraduate education, technology-applied universities pay more emphasis on professional pertinence; compared with higher vocational schools, technology-applied undergraduate students have more knowledge on basic theory. Some scholars have summed up the training target of technology-applied undergraduate universities as follows: "cultivate students with basic knowledge and capacity, and strong application skills as well as good comprehensive quality". The standards of setting up technology-applied 
universities in China should be based on the classification standards of the international classification, and the training target is to cultivate type 5A2 applied talents.

In short, in order to establish basic standards of higher learning institutions, we must first consider the orientation of schools. The International Standard Classification of Education (revised 1997) formulated by UNESCO lays the foundation of establishment standards of technology-applied universities in China. The cultivation of technology-applied talents is different from the education of academic research talents, or the training of technical personnel in higher vocational colleges.

\section{Standards}

Basic Standards On Personnel Training Mode. Highlighting the practice teaching link, and strengthening the practice teaching session. Practice teaching links should account for a large proportion of education system in technology-applied universities. Practical teaching links include experimental teaching, practical term, project teaching, graduation design, internships and so on.

Implementing modular teaching reform and optimizing the theoretical teaching system. In basic courses, professional basic courses and professional courses, teachers can set a number of targeted modules, and re-organize the course with different modules. Course modules support each other, highlight the cultivation of students' practical ability and comprehensive ability, and carry out the idea of cultivating "application" and "compound" talents. Particularly, cross courses modules fully embodies the cultivation of students' comprehensive abilities.

Schools should cooperate with enterprises closely, and realize the teaching model with dual system characteristic of school-enterprise cooperation.

Talent training mode is the most important way to achieve training target.

Standards on major setup. Course setting should reflect the overall training objectives of technology-applied universities. Basic courses, specialized basic courses, specialized courses and cross major courses must be selected on the basis of personnel training target. Different courses should interlock with each other and form an organic whole of talent training. There are two points worth paying attention to. First, professional courses must be increased, trying to cover about $50 \%$ of total hours. Second, cross professional courses should be increased, trying to account for $8 \%--10 \%$ of total hours.

Teaching contents should emphasize the training of practical ability. Curriculum content should be integrated. Repetitive and irrelevant teaching content should be deleted; teaching contents should be timely adjusted and updated to adapt to the development of science and technology.

Teaching methods in technology-applied universities should be heuristic teaching, discussion, case study and study in real enterprise environment, rather than simple indoctrination. Diversified teaching needs to be carried out; students should be encouraged to study independently and actively.

Assessment system should be established as a combination of knowledge and ability assessment. Rote learning is not acceptable. A variety of assessment methods, such as closed-book exam, open-book examination, theory plus practice, comprehensive tasks, design projects and papers can be used.

Basic standards of school enterprise cooperation. Enterprises can participate in the formulation of personnel training program, the setting up of majors, as well as the selection of curriculum and teaching content. The school authority can employ industry and enterprise experts to participate in Professional Construction Committee. Committee members need to meet regularly to discuss problems in the construction of specialized courses.

Enterprises can participate in practice teaching, including the construction of school laboratory and the establishment of practice teaching standards. Skilled craftsmen come from enterprises can guide students in practice session.

Enterprises can select excellent talents to serve as part-time teachers in schools, and take charge of some specialized courses in schools, especially the practical courses.

Enterprises need provide jobs for graduates, internship students and students in practice semester. Technology-applied universities should have a number of educational practice bases outside the 
campus. If conditions permit, the school needs to carry out "dual system" teaching activities and provides enterprises with tailored talents.

Teacher standards. School authority can organize teachers, especially young teachers to work in enterprises for a period of time, in order to improve teachers' practical abilities and professional qualities. Teachers should be encouraged to take part in all kinds of vocational qualification examinations. For colleges and universities which conditions are permitted, teachers can be arranged to work in enterprises regularly to carry out horizontal researches and grasp the latest development of science and technology.

Talent introduction. When recruiting teachers, employees with work experience should be regarded equally as employees with doctor or master degree.

Schools leaders need to employ experts from industry and enterprises as part-time teachers, undertake some courses or guide students to carry out practical activities. At present, some schools employ experts with great impact in industry as part-time professors, part-time vice presidents or directors of departments, since they can solve technology difficulties for school. This approach should be promoted, but the teaching abilities and theoretical levels of these experts should also be examined.

Policy making. For double quality teachers, schools should reward and incline to them in recruitment, professional title appraisal, salary and performance assessment. Through above measures, a team of special teachers with dual quality can be built.

\section{Acknowledgements}

Funded Project: this paper is supported by Foundation for Education and Science Projects of The Twelfth Five-Year Plan of Hunan, Research on Development Strategy of Technological-applied Undergraduate School (Project No:. XJK015BJD011); it is also a pilot project of Provincial Institution-locality Cooperation Program of Hunan (Hunan Jiao Tong [2016] No. 436).

\section{References}

[1] K.M. Hao, Y.Q. Wang, Study on the Structure of Higher Education in China, People's Education Press, Beijing, 1988.

[2] M.Y. Pan, M. Wu, Classification and orientation of higher education institutions, J. Fudan Education Forum. 1 (2003).

[3] Association of Universities (Colleges) of Applied Science, Local University Transformation and Development Research Center, Research Report on Practice and Policy of the Transition and Development of Local Universities and Colleges, 2013.

[4] F.M. Kong, S.M. Guo, X.H. Tang, et. al., Building Application-oriented Universities, first ed., Peking University Press, Beijing, 2006.

[5] Q. Xiong, X.G. Meng, Innovation of talent training mode in higher vocational education, J. University of Education Science. 1 (2005) 45-48.

[6] H. He, Z. Li, Exploration of multi-level talent cultivation model in universities, J. China Adult Education. 1 (2005)35-38.

[7] G.W. Dong, Z.B. Xiao, Y. Wang, Research and practice of cultivating applied talents among undergraduate students based on market demand, J. Core Chinese Periodicals. 551 (2008) 292.

[8] P.Y. Xu, Reflections on the personnel training mode of technology-applied universities, J. Meitan Higher Education. 4 (2004) 62-65.

[9] B. Ren, S. Liang, Y.S. Liu, Exploration and practice of talent training mode technology-applied universities, J. China Academic Journal Website. 22 (2004) 29-31. 
[10] S. G. Yao, Comparison and enlightenment of two kinds of technical universities in Germany, J. China University Teaching. 3 (2011).

[11] P. Li, Learn advanced vocational education experience from Germany and explore the method of building technology-applied universities, J. Journal of Wuhan Commercial Service College. 6 (2012).

[12] J. Li, Germany technology-applied universities teaching system and its referential significance, J. Journal of Beijing Institute of Technology. 6 (2008).

[13] Z.P. Sun, Reflections on the personnel training reform of technology-applied universities, J. China Higher Education Research. 4 (2011).

[14] Z.H. Wang, Constructing community of interests, promoting deep cooperation between schools and enterprises, J. China Higher Education. 3 (2011).

[15] X.J. Li, Comparative study of cultivating educational technology professionals among undergraduate students. East China Normal University.2009

[16] Y.H. Gao, Inquiry and enlightenment from the cooperation between corporations and applied science universities in German - a case study of Deggendorf University of Applied Sciences, J. Shaanxi Education ， Higher Education Edition. 4(2013).

[17] K. Qiu, D.Y. Liu, L.Q. Huang, Analyzing running modes of applied sciences universities in Europe, J. Journal of Chongqing University of Science and Technology, Social Science Edition. 9 (2013). 